\title{
Cartografia das experiências de bebês: traços dos agenciamentos e subjetivações em contextos de creche.
}

\author{
Julia Costa*, Gabriela G. de Campos Tebet.
}

\section{Resumo}

Para Larrosa (2002), o sujeito da experiência é sobretudo um espaço onde têm lugar os acontecimentos. Pensamos nos bebês, como seres que estão construindo sua individuação, portanto, se expõem aos acontecimentos. Não são ainda, subordinados a serem sujeitos da informação. Cartografar os bebês, busca registrar os agires deles no espaço da creche. É perceber como eles se relacionam com esse território, como territorializam e desterritorializam. Como se dão essas possíveis experiências, também os processos de individuação e subjetivação ao relacionar-se consigo, com os outros bebês, com o mobiliário, os brinquedos e também com os adultos.

\section{Palavras-chave:}

Bebê, cartografia, experiência.

\section{Introdução}

Essa pesquisa busca observar os bebês em seu cotidiano de uma creche pública do município de Vinhedo. As vivências dos bebês são registradas em materiais audiovisuais que depois são transformados em mapas cartográficos.

Pretende-se buscar elementos não percebidos facilmente na rotina dos bebês, e assim, elementos que contribuem para a sua individuação no espaço da Educação Infantil.

\section{Resultados e Discussão}

A pesquisa em campo teve duração de um semestre e fo realizada com bebês de 06 meses a 1 ano e 05 meses. Foram produzidos mapas que registraram os agenciamentos $\mathrm{e}$ as territorializações produzidas por eles. A observação permitiu perceber que os bebês são seres abertos a novos acontecimentos e por isso são mais passíveis de experiência. Significam o ambiente de forma diferente dos adultos.

A cartografia permitiu registrar as cenas sem intenção de interpretar. Também permitiu uma observação mais atenta, me permitiu viver uma própria experiência no ato de cartografar.

A seguir, um mapa feito durante a pesquisa que mostra as ações de uma bebê na sala do berçário.

Figura 1. Mapa: A cabana de cabeça para baixo.

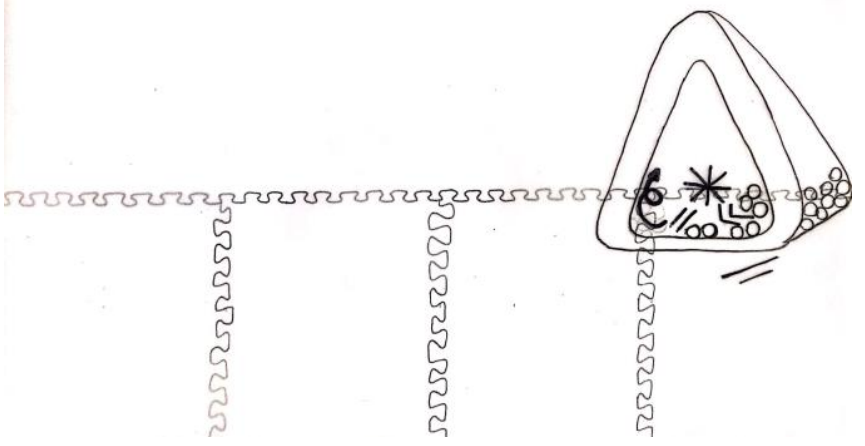

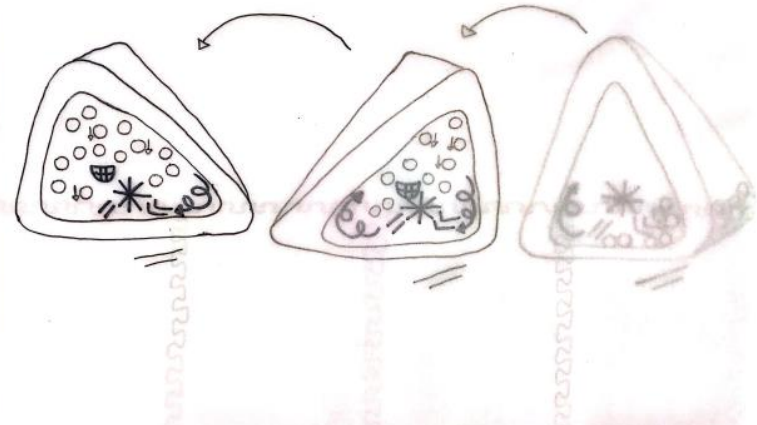

Figura 2. Legenda do mapa

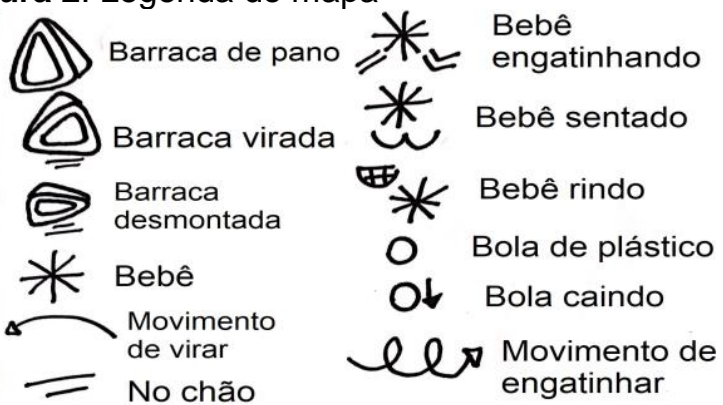

\section{Conclusões}

A cartografia de bebês é um estudo relativamente novo, mas potente, no sentido de que nos permite uma reflexão da prática pedagógica no ato de cartografar.

Nos permite adentrar no berçário com uma metodologia que respeita as particularidades do bebê.

\section{Agradecimentos}

Ao centro de Educação Infantil Pedrinho, por apoiar a pesquisa e conceder o espaço para observação dos bebês. 